\title{
PRODUCTIVITY OF ROSELLE/COWPEA INTERCROPPING SYSTEM IN A SEMI-ARID
} AGROECOLOGY

C. D. MUONEKE, I. O AKINGBADE and M. D. MAGAJI

(Received 24 October 2000, Revision accepted 15 March 2002).

\begin{abstract}
The effects of three planting densities $\left(27,700 ; 37,000\right.$ and 55,500 plants ha $\left.{ }^{-1}\right)$ of roselle grown sole or intercropped with cowpea were investigated in two field trials in the 1997 and 1998 wet seasons at Sokoto. The leaf area index (LAI) of roselle was highest with the highest roselle planting density in the sole or intercropping cultures in 1997, but in 1998 cropping season, planting density did not influence the LAI. Cowpea LAls were similar, except the lowest value obtained with cowpea intercropped with the lowest roselle pianting density.

intercropping did not affect the number of roselle pods per plant but reduced dry calyx yield by $39 \%$ and $36 \%(1997)$ and $33 \%$ and $38 \%(1998)$ when the lowest and the highest roselle populations were grown with cowpea. Yield reduction which was more for cowpea ranged from 34-46\% (1997) and 41-57\% (1998) and from $38-47 \%$ (1997) and $27-49 \%$ (1998) for number of pods/plant and grain yield/ha, respectively. The productivity of the roselle/cowpea culture showed yield advantage of $13 \%-70 \%(1997)$ and $38 \%-49 \%$ (1998) when the two crops were intercropped at higher roselle populations.
\end{abstract}

Keywords: Roselle, cowpea, intercropping, productivity

\section{INTRODUCTION}

Intercropping of two or more crops is a widely practiced cropping system in many developing countries of Africa, including Nigeria (Fawusi, 1985). In northern Nigeria, including Sokoto, Kebbi and Zamfara States, roselle, Hibiscus sabdariffa $L$. is now widely incorporated into the predominantly cereal and grain legume based cropping systems. In view of the rising commercial importance of roselle for its refreshing red calyx drink, which is medicinal, and as a source of fibre, the land area devoted to its cultivation, especially in mixtures is increasing in the northern States.

Research work on intercropped roselle is scanty. Only few works on roselle, especially monoculture agronomy such as those of Shalaby and Razin (1989) and Selim, et al., 1993 in Egypt had been reported. Because of the ubiquity of roselle/cowpea intercropping in the study area (Sokoto) and the dearth of documented information on the mixtures, a series of studies on roselle production, including the one reported in this paper was initiated. The yields obtained by the farmers are always very low due to among

other factors poor establishment and inadequate plant density. The farmers in the study area usually grow roselle and cowpea at the spacing of $0.60 \mathrm{~m} \times 0.45 \mathrm{~m}$ and $0.60 \mathrm{~m} \times 0.30 \mathrm{~m}$ or 37037 and 55500 plants ha ${ }^{-1}$ of the two crops in mixtures, respectively. The objective of the work was to investigate the effect of lower or higher roselle populations on the crops' productivity when intercropped with cowpea. It also aimed at

C. O. MUONEKE, Department of Agronomy, Michael Okpara University of Agriculture, Umudike, Nigeria

I. O. AKINGBADE, Department of Crop Sciences, Usmanu Danfodiyo University, Sokoto, Nigeria

M. D. MAGAJI, Department of Crop Sciences, Usmanu Danfodiyo University, Sokoto, Nigeria 
determining the optimum roselle planting density in intercrop with cowpea.

\section{MATRIALS AND METHODS}

Field experiments were conducted during the 1997 and 1998 wet seasons (July-November) at the Usmanu Danfodiyo University Sokoto Teaching and Research Farm located at Dabagi $\left(13^{\circ} 9^{\prime} \mathrm{N}, 5^{\circ} 12^{\prime} \mathrm{E}, 200 \mathrm{~m}\right.$ above sea level) about $38 \mathrm{~km}$ south of Sokoto town. Dabagi located within the semi-arid ecology is characterized by erratic rainfall lasting from June to September. It had a total rainfall of $346.7 \mathrm{~mm}$ in 1997 (JulyOctober) and $740.3 \mathrm{~mm}$ in 1998 (July-November). The soil was a sandy loam with acidic reaction which characteristics were as follows: Soil $\rho^{H} 5.8$

and 5.3 (1:2.5 soil: watero, organic carbon 0.50 and $0.48 \%$, total $N 0.02$ and $0.015 \%$, available $P$ 0.32 and $0.30 \mathrm{C} \mathrm{mol}(+) / \mathrm{kg}$, exchangeable $\mathrm{K} 4.61$ and $3.13 \mathrm{~mol}(+) / \mathrm{kg}$ for 1997 and 1998, respectively.

Three roselle planting densities $(27,700$; 37,000 and 55,500 plants ha $^{-1}$ ) were intercropped betwes:? rows of 55,500 cowpea plants ha ${ }^{-1}$ ). The roselle populations were obtained with different intra row spacings of $0.30,0.45$ and $0.60 \mathrm{~m}$ and at constant interrow $60 \mathrm{~cm}$ spacing. With the incorporation of three sole roselle densities and one sole cowpea density, three were seven treatments as follows: 27,700 sole roselle plants $\mathrm{ha}^{-1}, 37,000$ sole roselle plants $\mathrm{ha}^{-1}$, 55,500 sole roselle plants ha-1, 55,500 sole cowpea plants ha ${ }^{-1}, 27,700$ roselle plants $\mathrm{ha}^{-1}+$ 55,500 cowpea plants ha ${ }^{-1}, 37 \cdot 000$ roselle plants $\mathrm{ha}^{-1}+55,500$ cowpea plants $\mathrm{ha}^{-1}$ and 55,500 roselle plants ha $\mathrm{a}^{-1}+55,500$ cowpea. The roselle cultivar used was the 'Sokoto Red Calyx Variant' in both years. 'Sokoto White', an indeterminate local cowpea variety was used in 1997) but 'Dankalabachi' cowpea was used in 1998 because unavailability of 'Sokoto White'

The treatments were arranged in randomized complete block design with three replicates. Each plot measured $6 \mathrm{~m} \times 3 \mathrm{~m}$. In 1997, farmyard manure was applied to each plot at $10 \mathrm{t} \mathrm{ha}^{-1} 7$ days before seeds of both crops were sown on 1.4 August. The crops received 300 $\mathrm{kg} \mathrm{ha}{ }^{-1}$ of NPK 20: 10: 10 compound fertilizer 21 days after planting (DAP). In 1998, both crops were planted on 28th July. Seedlings were thinned to one per stand 14 DAP after which 250 $\mathrm{kg} \mathrm{ha} \mathrm{h}^{-1}$ of NPK 20: 10: 10 were applied immediately after weeding at 21 DAP. A second application of the same fertilizer mixture at $150 \mathrm{~kg}$ $\mathrm{ha}^{-1}$ was applied to the roselle crop 42 DAP (at the flower bud stage). Due to non availability of FYM in 1998, $400 \mathrm{~kg} \mathrm{ha}^{-1}$ NPK 20:10:10 fertilizer was used to boost the fertility of the soil

From 10 DAP, weekly spraying of roselle stands was done with vetox-85 (carbaryl) at $1.5 \mathrm{~kg}$ a.i ha ${ }^{-1}$ to control flea beetles (Pondagrica sjodstedti Jack).

The spraying was stopped 7 days before harvest. At 14 DAP, carbofuran (furadan) $3 G$ at $750 \mathrm{~kg}$ a.i. $\mathrm{ha}^{-1}$ was applied to cowpea to control Oetheca mutabilis Sahl.). Data on plant height (roselle), leaf area index (LAI) and total dry matter (TDM) for both crops were taken from four plants of each crop randomly from three inner rows at 70 DAP. The leaf area of roselle was determined from regression equation, $Y=1.0296+0.51 \times(r=$ $\left.0.70^{*}\right)$

developed by measuring the product $(X)$ of the length and breath of 100 leaves as well as areas obtained from metric graph papers during the field study. The leaf area of cowpea was estimated as the sum of all the products of the length (L) ant: broadest width $(W)$ of the terminal le multiplied by 2.325 , that is, $Y=2.325$ according to Osei- Yeboah, et al., (1983). The leaf areas of the crops were then converted to their leaf area indices. The plants were late: oven-dried at $70^{\circ} \mathrm{C}$ for 48 hours to obtain the dry matter yield. Data on yield components of eacin crop were taken from six plants from the inner rows. The data were analysed according to the procedures of a randomised complete block design and the treatment means were compared with the Duncan's new multiple range test at 0.05 level of significance.

\section{RESULTS AND DISCUSSION}

\section{Growth:}

There was no significant effect of roselle planting density nor intercropping on roselle plant height in 
Table 1: Effect of roselle planting density on growth of sole and intercropped roselle and cowpea at 70 days after planting in 199 and 1998 cropping seasons

$\begin{array}{lccccc}\text { Roselle } & \text { Planting } & \text { Plant } & \text { Vinc } & \text { No. of } & \text { Leal Total dry matter } \\ \text { planting } & \text { scheme } & \text { height } & \text { length } & \text { Branches } & \text { Area } \\ \text { density } & & (\mathrm{cm}) & (\mathrm{cm}) & \text { Plant } & \text { index }\end{array}$

plants ha 1 .

Roselle Cowpea Roselle Cowpea Roselle Cowpea
$\underline{1997}$

\begin{tabular}{|c|c|c|c|c|c|c|c|c|}
\hline 27700 & Sole & $78.3 \mathrm{c}$ & - & 140 & - & $0.40 b c$ & - & $1290 \mathrm{ab}$ \\
\hline 37000 & Sole & $87.3 a$ & - & 13.3 & - & $0.50 \mathrm{ab}$ & - & $1518 \mathrm{ab}$ \\
\hline 55500 & Sole & $84.0 \mathrm{a}$ & . & 13.3 & - & $0.60 \mathrm{a}$ & - & $1716 a$ \\
\hline
\end{tabular}

\begin{tabular}{|c|c|c|c|c|c|c|c|c|c|c|}
\hline Cowpe & & Sole & - & $128.7 \mathrm{a}$ & - & 5.0 & - & $3.4 \mathrm{a}$ & - & $11.6 \mathrm{a}$ \\
\hline 27700 & + & Cowpea & $78.7 \mathrm{a}$ & $111.2 \mathrm{a}$ & 12.7 & 5.0 & $0.30 \mathrm{c}$ & $2.0 \mathrm{~b}$ & $736 \mathrm{c}$ & $7.5 \mathrm{~b}$ \\
\hline 37000 & $t$ & Cowpea & $71.5 b$ & $98.0 \mathrm{a}$ & 10.3 & 5.0 & $0.50 \mathrm{ab}$ & $3.4 a$ & $1459 \mathrm{ab}$ & $8.7 b$ \\
\hline 55500 & + & Colvpea & $87.3 a 1$ & 84.56 & 11.7 & 5.3 & $0.50 a b$ & $3.2 \mathrm{a}$ & $1 / 82 a b$ & $6.7 b$ \\
\hline
\end{tabular}

\begin{tabular}{|c|c|c|c|c|c|c|c|c|c|}
\hline \multicolumn{10}{|c|}{1998} \\
\hline 27700 & Sole & 59.3 & - & 12.0 & - & 0.50 &. & $1117 \mathrm{a}$ & - \\
\hline 37000 & Sole & 66.3 & - & 11.5 & - & 0.60 & - & $1243 a$ & - \\
\hline 55500 & Sole & 69.2 & - & 10.3 & - & 0.80 & - & $1085 a$ & - \\
\hline Cowpea & Sole & - & 33.0 & - & 3.0 & - & 1.4 & - & 11.8 \\
\hline $27700+$ & Cowpea & 61.2 & 32.0 & 10.0 & 2.7 & 0.40 & 0.9 & $770 \mathrm{~b}$ & 9.5 \\
\hline $37000+$ & Cowpea & 68.2 & 35.0 & 10.5 & 3.3 & 0.50 & 1.0 & $797 b$ & 10.3 \\
\hline 55500 & Cowpea & 71.5 & 38.2 & 8.2 & 2.7 & 0.60 & 1.5 & $1027 \mathrm{a}$ & 12.8 \\
\hline
\end{tabular}

Within each column and for each year, means with different letter(s) are significantly different according to the Duncan's new multip: range (est $\mathrm{P}<0.05)$.

both years 1997 and 1998 except for the 37,000 roselle plants $\mathrm{ha}^{-1}$ intercropped with cowpea in which the shortest roselle plants were produced, (Table 1). Similarly, intercropping had no significant effect on vine length of cowpea, except in 1997 when the highest roselle density reduced the cowpea vine length. There was no effect of roselle planting density nor intercropping on the branching of roselle or cowpea. The roselle leaf area index $(\mathrm{LAI})$ was highest with the highest roselle planting density in sole or intercropped culture in 1997 but in 1998 cropping season, planting density did not influence roselle LAI. In 1998, there was heavy rainfall during the growth of the crops and roselle could not withstand the water logging that resulted. It showed this by 
Table 2: Yield and yield components of sole and inlercroped roselle and cowpea as influcnced by roselle planting density in 1997 and 1998 cropping seasons.

\begin{tabular}{|c|c|c|c|c|c|c|}
\hline \multirow{2}{*}{$\begin{array}{l}\text { Roselle } \\
\text { planting density } \\
\text { (plants ha ') }\end{array}$} & \multirow{2}{*}{$\begin{array}{l}\text { Planting } \\
\text { scheme }\end{array}$} & \multicolumn{2}{|c|}{ Roselle } & \multicolumn{3}{|c|}{ Cowpea } \\
\hline & & $\begin{array}{c}\text { No of calyx } \\
\text { bearing } \\
\text { pods plant } \\
\text { ha } 1\end{array}$ & $\begin{array}{c}\text { Dry calyx } \\
\text { yield } \\
\left(\mathrm{kg} \mathrm{ha}^{\mathrm{l}}\right)\end{array}$ & $\begin{array}{l}\text { No. of pods } \\
\text { plant ha }\end{array}$ & $\begin{array}{c}100 \text { grain } \\
\text { wt. } \\
\text { (g) }\end{array}$ & $\begin{array}{l}\text { 'Grain yield } \\
(\mathrm{kg} \text { ha ') }\end{array}$ \\
\hline \multicolumn{7}{|c|}{1997} \\
\hline 27700 & Sole & $22.0 \mathrm{a}$ & $140.7 b c$ & - & - & - \\
\hline 37000 & Sole & $15.3 \mathrm{abc}$ & $132.2 \mathrm{bc}$ & - & - & - \\
\hline 55500 & Sole & $14.0 b c$ & $191.1 \mathrm{a}$ & - & - & - \\
\hline Cowpea & Sole & - & - & $8.7 \mathrm{a}$ & 14.0 & $236.1 \mathrm{a}$ \\
\hline $27700+$ & Cowpea & $14.0 \mathrm{bc}$ & $85.6 \mathrm{a}$ & $4.7 b$ & 14.2 & $122.0 \mathrm{~b}$ \\
\hline $37000+$ & Cowpea & $18.3 a b$ & $168.4 a b$ & $4.7 b$ & 14.4 & $101.3 b$ \\
\hline $55500+$ & Cowpea & $9.3 \mathrm{c}$ & $\begin{array}{l}122.6 \mathrm{~cd} \\
1998 \\
\end{array}$ & $5.7 \mathrm{~b}$ & 14.1 & $139.4 \mathrm{~b}$ \\
\hline 27700 & Sole & $30.2 \mathrm{a}$ & $183.7 \mathrm{c}$ & - & - & - \\
\hline 37000 & Sole & $29.7 \mathrm{ab}$ & $228.4 b c$ & - & - & - \\
\hline 55500 & Sole & $23.8 b c$ & $333.7 \mathrm{a}$ & - & - & - \\
\hline Cowpea & Sole & - & - & $9.4 a$ & 14.5 & $189.9 \mathrm{a}$ \\
\hline $27700+$ & Cowpea & 26.7 & $123.3 \mathrm{~d}$ & $5.8 b$ & 14.2 & $138.8 \mathrm{~b}$ \\
\hline $37000+$ & Cowpea & $24.1 \mathrm{bc}$ & $198.9 b c$ & $5.0 \mathrm{~b}$ & 14.2 & $96.9 \mathrm{c}$ \\
\hline $55500+$ & Cowpea & $22.5 c$ & $205.7 b$ & $5.0 \mathrm{~b}$ & 14.2 & $119.1 \mathrm{bc}$ \\
\hline
\end{tabular}

Wịthin each column and for each year, means with different letter(s) are significantly different according to the Duncan's new multiple range lest $P<0.05$ ).

'Dry calyx yield at $10 \%$ moisture content

${ }^{2}$ Cowpea grain yield at $12 \%$ moisture content.

shedding most of its leaves. The crop had to recover later but not many leaves were formed again after this recovery. Cowpea LAls were similar except the lowest values obtained with cowpea intercropped with the lowest roselle density. This was surprising as it was expected that higher roselle populations would drastically reduce cowpea leaf production and expansion.

In 1997, the total dry matter of roselle was similar among the sole crops and roselle intercropped at higher densities but these were all higher than when intercropped with cowpea at the lowest roselle density. In 1998, the trend was similar except that the crop intercropped at the 
intermediate density also had the lowest dry matter. Sole cowpea in 1997 produced more dry matter than the intercrops but in 1998 there was no effect of the cropping systems on the dry matter. The higher dry matter with sole crop in 1997 compared to the intercrops could be due to its longer vines or shoots.

\section{Yield and Yield Components:}

In the sole roselle in both years, the number of calyx bearing pods plant ${ }^{-1}$ was highest with the lowest population (27,700 plants ha $\left.{ }^{-1}\right)$ while dry calyx yield $\mathrm{ha}^{-1}$ was highest with the highest roselle planting density $(55,500$ plants ha' ') but there was no difference between the 27,700 and 37,000 plants ha ${ }^{-1}$ (Table 2). In the intercrop in 1997, the number of calyx bearing pods plants $\mathrm{ha}^{-1}$ and dry calyx yield ha $\mathrm{a}^{-1}$ were highest with 37,000 roselle plants ha-1 but there was no difference in parameters between the lowest and the highest roselle planting densities.

Within each roselle planting density in both years, there was no significant effect of intercropping for

Table 3: Land equivalent ratio and gross monetary return of sole and intercropped roselle and cowpea in 1997 and 1998 cropping seasons.

\begin{tabular}{|c|c|c|c|c|c|c|c|}
\hline \multirow{3}{*}{$\begin{array}{l}\text { Roselle } \\
\text { planting } \\
\text { density } \\
\text { (plants ha }{ }^{-1} \text { ) }\end{array}$} & \multirow{3}{*}{$\begin{array}{l}\text { Planting } \\
\text { scheme }\end{array}$} & \multicolumn{3}{|c|}{ Land equivalent ratio } & \multicolumn{3}{|c|}{ Gross monetary return ( $\mathrm{N}$ (600 ha ${ }^{-1}$ ) } \\
\hline & & \multicolumn{2}{|c|}{ Partial } & \multirow[t]{2}{*}{ Total } & \multicolumn{2}{|c|}{ Partial } & \multirow[t]{2}{*}{ Total } \\
\hline & & Roselle & Cowpea & & Roselle & Cowpea & \\
\hline \multicolumn{8}{|c|}{1997} \\
\hline 27700 & Sole & 1 & - & 1 & 25.50 & - & 25.50 \\
\hline 37000 & Sole & 1 & - & 1 & 23.95 & - & 23.95 \\
\hline 55500 & Sole & 1 & - & 1 & 34.62 & - & 34.62 \\
\hline Cowpea & Sole & - & 1 & I & - & 4.94 & 4.94 \\
\hline \multicolumn{2}{|c|}{$27700+$ Cowpea } & 0.61 & 0.52 & 1.13 & 15.50 & 2.56 & 18.06 \\
\hline \multicolumn{2}{|c|}{$37000+$ Cowpea } & 1.27 & 0.43 & 1.70 & 30.51 & 2.21 & 32.73 \\
\hline \multicolumn{2}{|c|}{$55500+$ Cowpea } & 0.64 & 0.59 & 1.23 & 22.21 & 2.92 & 25.13 \\
\hline 27700 & Sole & 1 & - & $\mathrm{I}$ & 33.28 & - & 33.28 \\
\hline 37000 & Sole & 1 & - & 1 & 41.38 & - & 41.38 \\
\hline 55500 & Sole & 1 & - & 1 & 60.45 & - & 60.45 \\
\hline Cowpea & Sole & - & 1 & 1 & - & 3.97 & 3.97 \\
\hline \multicolumn{2}{|c|}{$27700+$ Cowpea } & 0.67 & 0.73 & 1.40 & 22.34 & 2.91 & 25.25 \\
\hline \multicolumn{2}{|c|}{$37000+$ Cowpea } & 0.87 & 0.51 & 1.38 & 36.03 & 2.03 & 38.06 \\
\hline \multicolumn{2}{|c|}{$55500+$ Cowpea } & 0.86 & 0.63 & 1.49 & 51.76 & 2.49 & 54.25 \\
\hline
\end{tabular}

"Prevailing market prices of the component crops at the time of harvest in both years.

$1 \mathrm{~kg}$ roselle dry calyx $=181.15$

$1 \mathrm{~kg}$ cowpea grain $=220.95$. 
number of pods plant ${ }^{-1}$ except with the 27,700 plants ha ${ }^{-1}$ in 1997 when intercropping reduced the number of pods plant ${ }^{-1}$. Intercropping reduced dry calyx yield in both years, except when 37,000 roselle plants $\mathrm{ha}^{-1}$ were intercropped with cowpea in which there was no difference between that and sole cropping system. Yield reductions of roselle due to intercropping were $39 \%$ and $36 \%(1997)$ and $33 \%$ and $38 \%(1998)$ when 27,700 and 55,500 roselle plants $\mathrm{ha}^{-1}$ were grown with cowpea, respectively. Intercropping roselle at 37,000 plants ha ${ }^{-1}$ did not affect roselle yield when compared with its yield at that sole population.

In 1997, growing cowpea in mixture with roselle at all the roselle populations reduced the number of pods plants ha ${ }^{\cdot}$ and grain yield, the reduction ranging from

$34 \%-46 \%$ for number of pods plants ${ }^{-1}$ and from $41 \%-57 \%$ for grain yield ha: Similarly in 1998 , the cowpea reduction due to intercropping ranged from $38 \%-47 \%$ and $27 \%-49 \%$ for pods and grain yields, respectively. The reduction was alvays highest when intercropped with 37,000 $r$ selle plants ha ${ }^{-1}$. Yields reduction due to intercropping could be due to competition for growth resources as advanced for other crops in mixtures by various workers (Willey, 1979, Remison, 1978, Muoneke, 1995, Muoneke and Asiegbu, 1997). The competition was even more ur cowpea as roselle planting density increased.

Yield reduction was more in cowpea than in roselle, probably due to flooding that resulted and smothered cowpea and reduced its population, especially in 1998 thus resulting in lower yield of cowpea in that year than in 1997.

\section{The Productivity of the Mixtures:}

Intercropping resulted in yield advantages in both years; the total land equivalent ratio(LER) was between 1.13 and 1.70 (1997) and between 1.38 and 1.49 (1998) thus showing higher productivity of between $13 \%$ and $70 \%$ due to intercropping (Table 3). In 1997, this yield advantage was highest with intercropping at 37,000 roselle plants $\mathrm{ha}^{-1}(70 \%)$ but in 1998 , growing the mixtures at the highest roselle population was most productive. The partial LER of the component crops showed that roselle aiways contributed more to the total yield than cowpea, except in 1998 when cowpea intercropped with 27,700 roselle population had more partial LER (0.73) than roselle. In 1997, for example, the roselle at 37,000 plants $\mathrm{ha}^{-1}$ contributed about three times more than cowpea in the total productivity of the mixture. The gross return increased as sole roselle increased in both years (Table 3) as reported by Muoneke and Asiegbu (1997) for okra/maize mixture. However, intercropping reduced gross monetary returns, except in 1997 in intercropping with 37,000 roselle plants ha ${ }^{-1}$ when the return of roselle increased. Lower parial gross returns of the components crops reflected in lower total gross returns of both components in intercrops compared with the sole crops. This might be due to depressed yield of both crops due to intercropping (Table 2). Although LER and yield advantages increased with intercropping, the reverse was the case with gross return. This reduced gross return in the work reported here did not agree with Ogbuehi and Orzolek (1987) view that intercropping where land is scarce would always generate a higher gross return per unit area of land compared to sole cropping. Willey (1979), lienkwe and Odurukwe (1990) as well as Kumar and Yusuf (1991) observed that the highest LER values would not always reflect the highest monetary return to the farmers. There will be need to evaluate some agronomic techniques such as component densities and fertilizer study to improve yield and increase the gross return. The work reported here did not take into account additional yield of cowpea hay, an important product in a ruminant livestock based farming system where it is even as important as grain yield. Inclusion of this might raise both LER and gross return and thus further improve the productivity of the cropping system.

In conclusion, the results show that sole roselle at 55,500 plants ha ${ }^{-1}$ followed by intercropping 37,000 roselle piants ha ${ }^{-1}$ and cowpea in 1997 or sole roselle at 55,500 plants ha ${ }^{-1}$ followed by 55,500 roselle plants ha ${ }^{-1}$ intercropped with cowpea in 1998 seemed to be 
most profitable. There is need for more work on this intercropping system which is prevalent in the study area and elsewhere but which had not been documented

\section{REFERENCES}

FAWUSI, M.O.A., 1985. Imfluence of spatial arrangements on the growth, fruit and grain yields and yiek components of intercropped maize and okra (Ahelmoschus esculkmma). Jield Crops Research 11: $345-352$

IFENKWL: O.P. and ODURUKWI: S.O. 1090. Potato/maize intercropping in the Jos plateau of Nigeria. Field Crops Research 25: $75 \ldots 82$.

KUMAR, V. and YUSUI, Y., 1991. Efrecls of row arrangements and component density of mixture on cotton/millet, cotton/gromdnut and cotton/maize. Nigeria Agricultural Journal 76: $43 \ldots 53$.

MUONEKE, C.O., 1995. Plant Population and Intercropping Studies in Okra (Abetmoschus esculentus L. Moench) with (Zea mass L.) and Cowpea ( Vigna my miculata L.Waip). Ph. D Thesis. University of Nigeria. Nsukka.

MUONEKE. C.O. and ASIEGBU, J.E. 1997. Effect of olka planting density and spatial arrangement in intercrop with maize on the growtl and yield of the component species. Journal of Agronony and Crop Science 179: $201-207$

OGBUEHI, C.R.A. and ORZOLEK, M.D., 1987. intercropping carrot and sweet corn in a multipie cropping system. Scientia itoriculurae 31: 17 24.
O.EEIF, I.M. and JOLAOSO, M.A., 1991. Growing cucumber with some other vegetables. Paper presented at the Anmual Conference of the Ilorticultural Society of Nigeria at the University of Nigeria, Nsukka, $3^{\text {1d }}-6^{\text {th }}$ November, 1991.

OSEI YEBOAII, S., LINDSAY, J.I and GUMBS, F.H. 1983. Estimating laaf area of cowpea ('Vigna unguiculuta $\mathrm{L}$. Walp.) from linear measurements of terminal leaflets. Tropical Agriculture $60(2) ; 149-150$.

RLMISON, S.U., 1978. Neighbour effects between maize and cowpea at various levels of $N$ and $P$. Experimental Agriculture 14:205-212

SELIM, S.M., HASSAN, M.R. and IIASSANAIN, M.A.

1993. Effect of sowing date. nitrogenous and potassium fertilizer on roselle plant. Effects on vegetative growth and llowering. Egyptian Journal of Horticulture 20 (1): $87-96$

SHALABY, A.S. and RAZIN, A.M., 1989. Effect of plant spacing on the productivity of roselle (hibiscus sabdariffa) grown in a newly reclaimed land. Journal of Agronomy and crop science 162 (4): 256 260.

WILLEY, R.W., 1979. Intercropping - its importance and research needs. 1. Competition and yield advantages. Field Crops Research 32 I: I - 10. 